https://doi.org/10.25143/socr.14.2019.2.053-063

\title{
Juridiskās izglītības jaunie izaicinājumi
}

\author{
Dr. iur. Andrejs Vilks \\ Rìgas Stradiṇa universitāte, Juridiskā fakultāte, Latvija \\ Andrejs.Vilks@rsu.lv
}

\section{Kopsavilkums}

Politiskās plānošanas dokumentos tiek atzīts, ka Latvijā samazinās juridiskās izglītības kvalitāte un tiesību zinātṇu studiju programmu absolventiem ir vājas zināšanas un prasmes jurisprudencē.

Lai paaugstinātu juridiskās izglìtības kvalitāti, Latvijas Republikas Ministru kabinets 2015. gadā akceptēja rīkojumu par valsts vienotā jurista kvalifikācijas eksāmena ieviešanu 2021. gadā profesionālajās maǵistrantūras studiju programmās "Tiesību zinātne", vienlaikus augstākās izglītības sistēmā likvidējot profesionālās bakalaura studiju programmas un liedzot studējošajiem iespēju iegūt juriskonsulta kvalifikāciju. Augstākās juridiskās izglītības sistēma kopumā tiek pārveidota. Valsts vienotā jurista kvalifikācijas eksāmena ieviešana rada nepieciešamību pārveidot studiju procesu, veikt izmaiṇas îstenotajos studiju kursos un papildināt prasības tiesību apakšnozarēs, kurās tiks pārbaudītas studējošo zināšanas vienotā eksāmenā.

Atslēgvārdi: jurists, juridiskā izglìtība, tiesību zinātne, valsts vienotais jurista kvalifikācijas eksāmens.

\section{levads}

Latvijas ekonomiskā attīstība, dinamiskie sociālie un tehnologiskie procesi, kuri izteikti izpaužas mūsdienu sabiedrībā, nosaka nepieciešamību sagatavot augsti kvalificētus speciālistus. Arī juridiskās izglītības sfērai ir īpaša nozīme augstvērtīgu, labi izglìtotu speciālistu sagatavošanā. Šì nozìme saistìta ne tikai ar valsts vajadzību pēc starptautiskajiem standartiem atbilstošiem juristiem, kam ir piemērots zināšanu, prasmju, iemaṇu un attieksmju potenciāls, bet arī ar visplašākā sabiedrības un patērētāju loka nepieciešamību pēc juridiskām zināšanām. Pakalpojumu tirgus segmenta paplašināšanās un tiesiska rakstura darījumu strauja pieauguma dēl juridiskās zināšanas nepieciešamas arī šo pakalpojumu san̦ēmējiem un darījumu slēdzējiem. Tādēl jāatzīst, ka tiesisko zināšanu objektīvais pieprasījums ir l̦oti plašs un tas pieaug. 


\section{Pārmaiṇas juridiskās izglītības sistēmā}

Juridiskās izglītības sistēmas pārveide un juristu sagatavošanas nosacỉjumu diezgan straujās izmain, ns nosaka Latvijas augstskolu un to juridisko fakultāšu mācību procesa organizācijas, studiju plānojuma, studiju kursu apguves un studējošo zināšanu pārbaudes un vērtēšanas pārstrukturēšanu.

Atbilstīgo izmaiṇu pamatā ir Ministru kabineta 2015. gada 16. februāra rīkojuma Nr. 78 "Par Valdības rīcības plānu Deklarācijas par Laimdotas Straujumas vadītā Ministru kabineta iecerēto darbību îstenošanai” pielikuma 34.1. apakšpunktā noteiktā rīcības plāna pasākums: "Lai ieviestu valsts vienoto juristu kvalifikācijas eksāmenu, paaugstinot un vienādojot prasības jurista kvalifikācijas iegūšanai, likvidēt juriskonsulta profesiju, izstrādāt konceptuālu ziņojumu par valsts vienotā juristu kvalifikācijas eksāmena ieviešanu un izstrādāt normatīvo aktu grozijumus, lai ieviestu minēto eksāmenu" [3].

Tieslietu ministrijas sagatavotajā Informatīvajā ziṇojumā "Par valsts vienotā jurista kvalifikācijas eksāmena ieviešanu” [8] tika atzīts, ka kopš pagājušā gadsimta 90. gadu sākuma, attīstoties brīvā tirgus ekonomikai, pieauga tiesību zinātṇu studiju programmu skaits, kas ilgtermiņā samazināja juridiskās izglītības kvalitāti valstī. Turklāt var konstatēt, ka šajā Informatīvajā ziņojumā un arī citos politiskās plānošanas dokumentos netika publiskoti argumenti, kuri apliecinātu juridiskās izglīīibas kvalitātes pazemināšanos. Atbilstīgajos dokumentos netika ietverta informācija par to, kura līmeņa studiju programmās tiesisko zināšanu, prasmju, iemaņu un kompetenču samazinājums ir fiksēts, kura tipa mācību iestādēs un kurās studiju programmās - akadēmiskajās vai profesionālajās tas tika pieḷauts. Informatīvajā ziṇojumā vien atzīts, ka lielai dal̦ai tiesību zinātṇu studiju programmu absolventu ir diezgan vājas zināšanas un prasmes jurisprudencē. Taču nav minēts, ar ko un kā tas pierādìts.

Vēl arī tiek atzīmēts, ka "katra augstskola pēc saviem ieskatiem vērtē studentu teorētiskās zināšanas un prasmes, lai pieškirtu valsts atzìtu augstākās izglītības diplomu ar jurista vai juriskonsulta kvalifikāciju". Studentu teorētiskās zināšanas un prasmes augstskolas vērtē atbilstoši Augstskolu likuma [1,58. pants] un Profesionālās izglītības $[4,29$. pants] likuma prasībām. Izglītības likuma, Vispārējās izglīīibas likuma, Profesionālās izglìtîbas likuma, Augstskolu likuma un citu ar izglìtību saistìto normatīvo aktu ievērošanu kontrolē Izglīitibas kvalitātes valsts dienests - atbilstīgi Izglìtības likuma 20. pantam [2]. Atkāpes vai neatbilstības par augstskolas nepamatoti piešķirtu valsts atzìtu augstākās izglītības diplomu ar jurista vai juriskonsulta kvalifikāciju Latvijā nav konstatētas.

Pamatotu un objektīvu argumentu izmantošana normatīva rakstura dokumentos, it īpaši tajos, kas skar tiesisko jomu, ir profesionālās un ètiskās atbildības jautājums, kas ne vienmēr tiek ievērots politikas plānošanas dokumentos. 
Informatīvajā ziṇojumā minēts, ka veidojas diskusijas par nepieciešamību paaugstināt jurista kvalifikācijas iegūšanas prasības. Tātad, no vienas puses, bez pamatota atzinuma tiek apgalvots, ka Latvijā samazinās juridiskās izglīiības kvalitāte, no otras puses, ir nepieciešamība paaugstināt jurista kvalifikācijas iegūšanas prasības. Vai šajā gadījumā logiskāk nebūtu, pirmkārt, tomēr noteikt pašreizējo juridiskās izglītības kvalitātes līmeni, apzināt neatbilstības un nepilnības; otrkārt, diagnosticējot nepilnības konkrētās mācību iestādēs un studiju programmās, izstrādāt un īstenot nepilnību un neatbilstību novēršanas pasākumus vai attiecīgo studiju programmu pārtraukt îstenot; treškārt, izstrādāt pārdomātu jurista kvalifikācijas iegūšanas procedūru, lai jaunajiem nozares speciālistiem paaugstinātu prasības.

Atbilstošas procedūras izstrādes sākumposmā nepieciešams atbildēt uz jautājumu, vai valsts vienotais juristu kvalifikācijas eksāmens nodrošinās būtiski jaunu jurista kvalifikācijas kvalitāti? Vai juriskonsulta profesijas likvidēšana ir pamatotākais un atbilstošākais celıš, paaugstinot juridiskās izglìtības kvalitāti un nosakot jaunas, augstākas prasības jurista kvalifikācijas iegūšanā? Nav kādā veidā pierādīts un argumentēts tas, ka, likvidējot profesionālās bakalaura studiju programmas, kas nodrošināja juriskonsulta kvalifikācijas iegūšanu, pieaugs juridiskās izglīitibas kvalitāte.

Tieslietu ministrijas sagatavotajā Informatīvajā ziṇojumā "Par valsts vienotā jurista kvalifikācijas eksāmena ieviešanu” tiek salīdzināts juriskonsulta un jurista statuss. Pilnīgi pamatoti tiek atzìts, ka persona ar juriskonsulta kvalifikāciju nevar veikt tiesneša, prokurora, zvērināta advokāta, zvērināta notāra, zvērināta tiesu izpildītāja vai maksātnespējas administratora darbu, kā arī veikt darbu citās profesijās, kurās nepieciešama jurista kvalifikācija. [8]

Vēl jāpiebilst, ka jurista kvalifikācija nenozīmē to, ka persona ar atbilstīgu kvalifikāciju uzreiz var ien,emt šeit minētos amatus. Vajadzīgs arī sagatavošanās periods un jānokārto atbilstīgi kvalifikācijas eksāmeni. Tiek atzìts, ka šĩ ir viena no divām būtiskākajām atškirīibām starp jurista un juriskonsulta profesiju.

Otra būtiskākā atšḳirība starp jurista un juriskonsulta profesiju ir kompetence izstrādāt pētìjumus ar zinātnisku vērtību jurisprudencē. Tā vajadzīga juristiem, bet nav nepieciešama juriskonsultiem. Bet vai visiem, kuri strādā tiesību jomā, ir nepieciešams un ir arī aicinājums izstrādāt pētījumus ar zinātnisku vērtību jurisprudencēe Kāds ir definējumā ietvertais saturs - pētījumi ar zinātnisku vērtību jurisprudencē? Vai nepietiek ar prakses materiālu apkopojumiem un analīzi, kas veikta par sekmīgi izstrādātiem un aizstāvētiem profesionāliem bakalaura darbiem, kuri sagatavoti, iegūstot juriskonsulta kvalifikāciju? Un kas nosaka pētijumu jurisprudencē zinātnisko vērtību, ja pašiem juristiem daudzos gadijjumos nav vienota viedokḷa? 
Juristu un juriskonsultu kompetenču salīdzinošais modelis ir pat vairāk nekā interesants... Informatīvajā ziṇojumā konstatēts, ka

"profesiju klasifikatorā ietvertais abu profesiju nošḳīrums ir mākslīgs un formāls, jo pēc būtības pamatuzdevumi juristam un juriskonsultam ir gandrīz identiski:

- lai izstrādātu juridiskus dokumentus (kā tas ir paredzēts juriskonsultam), absolūtajā vairākumā gadījumu nepieciešams atrast, analizēt, tulkot un piemērot tiesību normas (kā tas ir paredzēts juristam);

- pārstāvība tiesās un citās institūcijas (kā tas ir paredzēts juriskonsultam) ietver sevī to pašu "tiesību subjektu pārstāvību", kas paredzēta juristam;

- procesuālo tiesību jomu nodalīšana (civilprocess, administratīvais process utt.) abās minētajās profesijās nav saprotama." [8]

Publisko tiesību joma, kas norādīta kā juriskonsulta darbības nozare, no tiesību teorijas viedokḷa raugoties, ietver sevī šādas tiesību nozares: konstitucionālās tiesības, administratīiās tiesības, finanšu tiesības, krimināltiesības, ekologiskās tiesības, kriminālprocesuālās un civilprocesuālās, kā arī starptautiskās publiskās tiesības [7, 57].

Izmantojot tik plašu terminu juriskonsulta pamatuzdevumu definēšanā, var secināt, ka darbības procesuālo tiesību jomā juristam un juriskonsultam pēc būtības neatšķiras.

No minētās salīdzinošās analīzes pēc būtības var izdarìt divus secinājumus: pirmkārt, ja profesionālajās bakalaura studiju programmās, kurās paredzēta juriskonsulta kvalifikācijas iegūšana, studējošie gūst gandrīz tikpat plašas zināšanas, praksē nepieciešamās prasmes, iemaṇas un kompetences, kuras ir jurista profesijas standartā, kādēl šo studiju programmu beidzējiem vēl jāmācās profesionālajā magistrantūras studiju programmā, kura satur līdzīgas zināšanas, prasmes un iemaņas. Vēl vairāk, rūpīgāk analizējot juriskonsulta un jurista profesiju standartos ietvertos pamatuzdevumus, kuri minēti Informatīvajā ziņ̧ojumā, redzams, ka pirmajā profesijas standartā tie ir plašāki (civilprocesā, administratīvajā procesā, disciplinārlietās, publisko, kā arī starptautisko un Eiropas Savienības (Kopienu) tiesību jomā paredzēts veikt darbības, kas saistītas ar materiālo un procesuālo tiesību normu piemērošanu un tiesu prakses izmantošanu).

Otrkārt, tiek atzìts, ka mērḳtiecīgi ir izveidot pamatotu juridisko profesiju un tai atbilstīgu tiesību zinātṇu programmu sistēmu, kā arī nepieciešams veikt pasākumus juriskonsulta profesijas likvidēšanai. Rezultātā paliktu divas savstarpēji skaidri nodalāmas juridiskās profesijas - jurists un jurista palīgs - ar saprotamām un pamatotām atšķirībām nepieciešamo zināšanu un prasmju apguvē. Visai dīvaini ir tas, ka viena no nepieciešamības paaugstināt prasības jurista kvalifikācijas iegūšanai rezultējošām darbībām ir profesionālo bakalaura studiju programmu "Tiesību zinātne" slēgšana un juriskonsulta profesijas likvidēšana. Arī tiesību zinātnieks Artūrs Gaveiko, pētot juridiskās izglīīibas reformu tendences Latvijā, ir secinājis, ka "juriskonsulta profesijas likvidēšana ir nepārdomāta, nepamatota un nelogiska, jo juriskonsulta profesija pēc 2017. gadā pien̦emtā jaunā profesiju klasifikatora ir vecāko juridisko lietu speciālistu sarakstā..." [7, 121]. 
Latvijā bija (pagaidām, līdz 2020. gadam, arī ir) iespējams iegūt gan tādu bakalaura grādu, kas ḷauj strādāt jurista profesijā (profesionālā bakalaura grāds tiesību zinātnēs ar juriskonsulta kvalifikāciju), gan tādu, kas dod tikai akadēmiskas zināšanas un uzskatāms vien par pirmo soli turpmākām studijām maǵistrantūrā (sociālo zinātṇu bakalaura grāds tiesību zinātnē bez profesionālās kvalifikācijas). Arī magistrantūras studiju rezultāts atkarībā no izvēlētās studiju programmas būtiski atšḳiras: sociālo zinātṇu maǵistra grāds tiesību zinātnē, absolvējot akadēmisko mağistrantūras studiju programmu, un profesionālais mag̣istra grāds tiesībzinātnē, kas dod kvalifikāciju "jurists" (no 2021. gada - pēc vienotā valsts jurista kvalifikācijas eksāmena veiksmīgas nokārtošanas).

Studiju programmu iedalījums akadēmiskajās un profesionālajās kā bakalaura, tā maǵistrantūras studiju līmenī ir nosacìts. Akadēmiskajās studiju programmās vairāk uzmanības pievērsts teorētiska rakstura mācību disciplīnām, tāpēc, beidzot šis studiju programmas, absolventiem nākas saskarties ar praktiska rakstura zināšanu, prasmju un iemaṇu trūkumu. Akadēmiskajās studiju programmās nav paredzētas prakses, kaut gan studiju plānos tās var būt iekḷautas, tomēr prakšu apjoms ir neliels. Prakses iekḷaušana akadēmiskajā bakalaura studiju programmā attiecīgi samazina tajā piedāvātos studiju kursus.

Savukārt profesionālajās studiju programmās mazāk ietverti teorētiski mācību kursi. Taču pastāvīga sociālās, politiskās un tiesiskās vides pārveide, nepārtrauktais tiesiskās jaunrades process gan nacionālā, gan starptautiskā līmenī nosaka, ka arī profesionālajās studiju programmās iespējami vairāk būtu jāietver teorētiskie mācību priekšmeti. Pèc akadēmisko studiju programmu un arī profesionālo bakalaura studiju beigām, iegūstot atbilstīgu kvalifikāciju, studējošie tomēr ir tendēti turpināt mācības maǵistrantūrā (profesionālajā), lai iegūtu jurista kvalifikāciju.

\section{Par vienoto valsts jurista kvalifikācijas eksāmenu}

Ieviešot jaunu topošo juristu zināšanu, prasmju un kompetenču pārbaudes un vērtēšanas sistēmu, rodas bažas, vai valsts vienotais jurista kvalifikācijas eksāmens l̦aus sasniegt izvirzìto mērkị, proti, paaugstināt juristu kvalitātes līmeni. Pašreiz ir grūti to novērtēt. Eksāmena ieviešana varētu sekmēt studējošo motivācijas paaugstināšanos, dziḷāku un noturīgāku zināšanu apgūšanu tiesību studiju programmās, un to var vērtēt pozitīvi. Taču tas varētu neattiekties uz pilnīgi visiem studējošajiem. Skaidras atbildes nebūs arī pēc pirmajām valsts vienotā jurista kvalifikācijas eksāmena kārtošanas reizēm. Juridisko zināšanu un prasmju kvalitātes noteikšanas metodiku nevar saistìt tikai ar pieņemtajiem Ministru kabineta noteikumiem. Vienlaikus jāatzīst - valsts pārvaldes institūcijās nav noteikti kritēriji un izveidota metodika, kas l̦autu diagnosticēt juridisko zināšanu un prasmju līmeni. Tas attiecas ne tikai uz augstskolu tiesību zinātṇu studiju programmu absolventiem, bet arī uz praktizējošiem juristiem.

Jaunā pārbaudījumu kārtība viesīs diezgan lielas izmaiņas tiesību zinātṇu studiju programmu plānošanā, organizēšanā un ieviešanā. Valsts vienotajā jurista kvalifikācijas eksāmenā iekḷautās jomas, kurās pārbaudīs studentu zināšanas un prasmes, liek maǵistrantūras studiju programmā atteikties no specializācijas studiju kursiem un programmā 
iekḷaut jaunus kursus, piemēram, krimināltiesību un kriminālprocesa aktuālās problēmas, civiltiesību, civilprocesa un komerctiesību aktualitātes, moduli par konstitucionālajām, administratīvajām un administratīvā procesa tiesībām u. c.

Valsts vienotajam jurista kvalifikācijas eksāmenam paredzēta teorētiskā daḷa (izvērstas atbildes uz jautājumiem rakstveidā) un praktiskā daḷa (praktisku uzdevumu (kāzusu) risinājums rakstveidā). Eksāmens tiks organizēts šādās tiesību nozarēs:

- krimināltiesībās un kriminālprocesa tiesībās;

- civiltiesībās, civilprocesa tiesībās un komerctiesībās;

- konstitucionālās tiesībās, administratīvās tiesībās un administratīvā procesa tiesībās;

- starptautiskās un Eiropas Savienības tiesībās;

- tiesību teorijā, tiesību filozofijā un Latvijas tiesību vēsturē.

Tādējādi saskaramies ar jaunu pieeju studiju kursu plānošanā, kas kopumā, iespējams, nebūtu jāvērtē negatīvi, taču tā visai specifiski ietekmēs augstskolu autonomiju. Joprojām neatbildēti ir jautājumi par komisijas locekḷu kvantitatīvo pārstāvniecību. Var paredzēt, ka eksāmenu organizācijas procesā nebūs iespējams nodrošināt tās kvalitatīvo atbilstību (kā prasìts noteikumos - nodrošināt komisijas locekḷu skaitu proporcionāli studējošo skaitam). Šajā noteikumu punktā nav paredzēts, ka komisijas sastāvā būs atbilstošs skaits jomu pārstāvju, kas varēs vērtēt teorētiskās daḷas atbilžu pareizību un kāzusu risinājumu precizitāti. Tāpat nav arī skaidrs, kādi būs kritēriji, saturs un prasības, kas būs noteiktas valsts vienotā jurista kvalifikācijas eksāmena vērtēšanas metodikā, kuru apstiprinās pati komisija. Šis varētu būt riska elements caurskatāmībai un vienveidīgai izpratnei eksāmena jautājumu izstrādes gaitā un eksāmena atbilžu izvērtēšanā.

Valsts vienotā jurista kvalifikācijas eksāmena organizēšanā būs jānemem vērā svarīgi aspekti:

- eksāmena kārtošanai tiks izveidota un uzturēta elektroniskā vide, kurā notiks kvalifikācijas eksāmens (Tieslietu ministrija šo uzdevumu delegē Latvijas Universitātei, noslēdzot delegeěšanas līgumu);

- vērtēšanas komisijas locekḷus varēs iekḷaut komisijas sastāvā atkārtoti jaunu eksāmenu kārtošanas gadījumos;

- komisijas locekl̦us uz pirmo sēdi sasauks tieslietu ministrs. Lìdz brīdim, kad komisija ievēlēs komisijas priekšsēdētāju un komisijas priekšsēdētāja vietnieku, komisijas sēdi vadīs tieslietu ministra pilnvarota persona;

- komisijas priekšsēdētājs un tā vietnieks nedrīkstēs būt augstskolas pārstāvis vai juridisko nozari pārstāvošas organizācijas pārstāvis, kurš piedalās studiju programmas īstenošanā augstskolā;

- studējošie kvalifikācijas eksāmenu kārtos vienlaikus tiešsaistē, izmantojot elektronisko vidi. Piekḷuves tiesības elektroniskās vides kvalifikācijas eksāmena sadal̦ai būs Tieslietu ministrijai, komisijas locekḷiem un studējošajiem. Atbilstošu eksāmena norises darba vidi un aprīkojumu nodrošinās augstskolas;

- augstskolai būs jāsniedz informācija par studējošo skaitu, kuri kārtos minēto eksāmenu, trīs mēnešus pirms ziemas un vasaras sesijas sākšanās - iepriekšējā viena mēneša laikā. 
Neapšaubāmi, ka augstskolas gatavojas ne tikai valsts vienotā jurista kvalifikācijas eksāmena ieviešanai, bet arī mainìt visai stabilu studiju procesu un studiju kursu plānojumu. Rīgas Stradiṇa universitātes Juridiskās fakultātes profesionālajā magistrantūras studiju programmā vajadzēs iekḷaut dạ̣eji jau bakalaura studiju programmā ĩstenotos studiju kursus, ietverot tajos problemātiskos aspektus, plašāk lietojot kāzusu risināšanu. Droši vien daḷēji vajadzēs attiekties no specializāciju studiju kursiem.

\section{Rīgas Stradiṇa universitātes pieredze juristu sagatavošanā}

Rīgas Stradiṇa universitātes Juridiskā fakultāte 2019. gada jūnijā svinēja desmit gadus kopš tās izveides. Desmit gadi nav sevišḳi liels laika periods. Tomēr šì ir respektējama jubileja Latvijas vispāratzītas mācību iestādes vienai no jaunākajām fakultātēm. Rīgas Stradiña universitātes tradīcijas juridiska rakstura studiju kursu îstenošanā gan ir senākas. Medicīnas un sabiedrības veselības fakultātē tika pasniegti tiesību pamatu studiju kursi. Eiropas studiju fakultātē sociologi studēja deviantologiju un kriminologiiju.

Par šìs fakultātes dekānu 2004. gadā tika ievēlēts Dr. iur. Andrejs Vilks. Sadarbībā ar RSU vadību (rektoru profesoru Jāni Vētru un prorektori profesori Ilzi Akotu) tika apspriesta iecere veidot tiesību zinātṇu studiju programmas. Uz sociālām zinātnēm Eiropas studijās varēja attiecināt arī daudzveidīgus tiesību zinātṇu studiju kursus. 2004. gadā sākās darbs pie akadēmiskās bakalaura un profesionālās maǵistra studiju programmas tiesību zinātnēs izveides. 2005. gadā minētās studiju programmas Augstākās izglìtības kvalitātes novērtēšanas centrā tika licencētas, un 2005./2006. akadēmiskajā mācību gadā sākās studējošo uzṇemšana. Licencēšana tikai nupat bija notikusi, tāpēc jaunās studiju programmas plašsaziṇas līdzekḷos netika reklamētas un informācija par tām arī RSU mājaslapā bija visai skopa. Tiem, kas vēlējās studēt tiesību zinātnes, kā tas bija arī visās pārējās sociālo zinātṇu studiju programmās, studiju maksa bija jāsedz no saviem vai tuvinieku līdzekḷiem. Loǵiski, ka cerēt uz lielu reflektantu skaitu būtu naivi. Pirmajā uzṇemšanā jaunajās studiju programmās pieteicās un mācības uzsāka desmit bakalaura grāda pretendentes (desmit jaukas meitenes) un 25 mağistranti. Tie bija Juridiskās fakultātes izveides pirmsākumi RSU.

Tiesību zinātṇu studiju programmu îstenošanas organizācija - no tās sākuma un arī vēlāk jau Juridiskās fakultātes ietvaros - tika īstenota, pārmantojot labākās tradīcijas un pieredzi no citām sociālo zinātṇu studiju programmām, - mācības pēc moduḷu principa (lielākā dal̦a studiju kursu tika realizēti ḷoti intensīvi viena mēneša laikā, bet nozīmīgākie studiju kursi - visu semestri, iztiekot bez "karstajiem" sesiju laika periodiem semestra beigās). Studiju programmās bija iekḷauts liels patstāvīgā darba apjoms un praktizējošu juristu iesaistǐšanās mācību procesā. N̦emot vērā izteikto Rìgas Stradina universitātes profesionālo ievirzi, izstrādājot un arī turpmāk pilnveidojot studiju programmu, tajā tika iekḷauti ar veselības aprūpi cieši saistīti studiju kursi: Medicīnas tiesības, Pacientu tiesības, Farmācijas tiesības, Biomedicinas tiesiskās problēmas, Tiesu medicīna, Tiesu psihiatrija u. c. 
Tiesību studiju kursus īstenoja autoritatīvākie tiesību apakšnozaru speciālisti, piemēram, Dr. habil. iur. Osvalds Joksts, Dr. hist. Valdis Blūzma, Dr. iur. Uldis Ķinis, Dr. iur. Jānis Grasis. Studiju programmā tika iesaistīti arī citu fakultāšu mācībspēki. Medicīnas tiesību bloku sākotnēji atzīstami îstenoja Medicīnas tiesību institūta vadītāja Solvita Olsena.

Eiropas studiju fakultāte 2004.-2005. gadā auga kvalitatīvi un kvantitatīii. 2005. gadā uz fakultātes bāzes tika izveidota Komunikāciju fakultāte un Tiesību institūts, kurš tika iekḷauts zinātnisko institūciju registrā. Pieaugot studējošo skaitam, 2009. gadā ar RSU Senāta lēmumu tika izveidota Juridiskā fakultāte. Pēc RSU sociālajās zinātnēs studējošo lūguma tika radīta akadēmiskā maǵistrantūras studiju programma.

Juridiskā fakultāte - kopš tās izveides pirmsākumiem un visā tās pastāvēšanas laikā - ir saṇēmusi universitātes vadības atbalstu. Toreiz, kad izveidojās Juridiskā fakultāte, bija skaidrs, ka tiks likvidēta Latvijas Policijas akadēmija (LPA), ar kuru RSU bija laba un lietišḳa sadarbība. Profesionālā bakalaura studiju programma "Tiesību zinātne", kura tika realizēta LPA un gatavoja speciālistus tiesībsargājošām iestādēm, tostarp Valsts policijai, tika likvidēta. Universitātes vadītāji (rektors profesors Jānis Gardovskis un prorektore profesore Ilze Akota) ieteica izstrādāt profesionālo bakalaura studiju programmu ar praktisku ievirzi un specializāciju policijas darbā. 2010. gadā tika licencēta profesionālā bakalaura studiju programma "Tiesību zinātne", kurā bija ietverti studiju kursi, kas tieši saistīti ar policijas darbu. 2011. gadā tika noslēgts līgums ar Valsts policiju par policijas darbinieku apmācību minētajā bakalaura studiju programmā. Taču liela daḷa policijas darbinieku turpināja izglīî̉bu maǵistrantūras studiju programmā. Savā darbā vinini veica operatīvās darbības, tāpēc programma tika papildināta ar specializāciju "Operatīvais darbs". Specializācijas studiju kursus docēja un docē augsti kvalificēti operatīvo dienestu vadìtāji un speciālisti no Latvijas, Igaunijas, Lietuvas un Zviedrijas. Reflektantiem bija diezgan liela interese par profesionālo bakalaura studiju programmu. Studējošie vairāk vēlējās apgūt studiju kursus ar praktisku ievirzi, gūt prasmes un iemaṇas juridisko dokumentu izstrādē un kāzusu risināšanā. Tomēr no 2020. gada šìs studiju programmas Latvijas augstskolās, arī RSU, netiks ìstenotas un netiks gatavoti jauni juriskonsulti, lai gan šĩs kvalifikācijas speciālisti Latvijā ir nepieciešami. Programmu un kvalifikāciju likvidēšana var novest pie analogas situācijas ar LPA likvidāciju, kura tagad tiek atzīta par kḷūdu, ko labot vairs nav iespējams.

Kopš tiesību studiju programmu izveides RSU bakalaura studiju programmu ir beiguši 1285 jauni tiesību speciālisti, t. sk. 651 sociālo zinātṇu maǵistrs tiesību zinātnē. Pašreiz Juridiskajā fakultātē ir vairāk nekā 800 studējošo. Kopš 2010. gada tajā tiek istenota doktorantūras studiju programma "Juridiskās zinātnes", kuru absolvējuši 72 doktoranti. RSU Promocijas padomē tika vērtēti 16 promocijas darbi, kuru autori ir ieguvuši tiesību zinātṇu doktora grādu. Ar augstskolas izdevniecības atbalstu Juridiskā fakultāte kopš 2015. gada regulāri izdod elektronisko juridisko žurnālu "Socrates", ar kura jaunāko numuru lasītājs patlaban iepazìstas. 
Juridiskās fakultātes absolventi ir augstas klases speciālisti, kas strādā tiesībsargājošās iestādēs (Korupcijas novēršanas un apkarošanas birojā, prokuratūrā, Valsts ieñēmumu dienestā, policijā u. c.), kā arī valsts un pašvaldību iestādēs un privātajās struktūrās. Daudzi maǵistrantūras studiju programmas absolventi turpina studijas doktorantūrā un docē atsevišḳus studiju kursus (Karina Palkova, Agnese Reine-Vìtina, Valdis Savickis, Laura Šāberte, Karina Zalcmane u. c.). Atsevišķi Juridiskās fakultātes absolventi turpina studijas ārvalstīs un aizstāv tur promocijas darbus, piemēram, Santa Slokenberga, kas 2016. gadā aizstāvēja promocijas darbu medicīnas tiesībās un tagad ir vairāku projektu vadītāja. Viṇas vadībā ir tapusi mācību grāmata "Medicīnas tiesības" [9] un "Pacientu tiesību likuma komentāri" [10]. Starp Juridiskās fakultātes mācībspēkiem ir daudzi tiesību nozaru ietekmīgākie speciālisti: profesors Dr. habil. iur. Osvalds Joksts, profesore Dr. iur. Sandra Kaija, asociētais profesors Dr. iur. Jānis Baumanis, asociētais profesors Dr. iur. Jānis Grasis, asociētais profesors Dr. iur. Uldis Kinis, asociētais profesors Dr. iur. Aldis Lieljuksis, docente Dr. iur. Inga Kudeikina, docents Dr. iur. Valdis Voins u. c.

RSU vienmēr ir jūtams kopējais vienotais gars, kas veicina universitātes kḷū̌̌anu par reputācijas līderi Latvijas augstskolu vidē. Augstskolas stingrās prasības akadēmiskajam personālam un studējošiem attiecas arī uz Juridisko fakultāti, kurā tiek nemitīgi attīstìta mācību procesa organizēšana, turpinās uzlabojumi docēšanā un studijās, noteikto rezultātu sasniegšanā. Juridiskajā fakultātē îstenojamās studiju programmās liela loma ir arī citām struktūrvienībām: Studiju departamentam, Pedagogíiskās izaugsmes centram, Valodu centram, bibliotēkai, Informācijas tehnologiju departamentam, Infrastruktūras departamentam u. c.

Kopš 2016. gada Juridiskā fakultāte atrodas jaunās, renovētās telpās, tomēr 2022. gadā to sagaida pārmainas - fakultāte tiks izvietota Kuldīgas ielā speciāli projektētās un aprīkotās telpās (būs policijas darba kabinets, kriminālistikas laboratorija, informācijas tehnologiiju centrs, speciālā auditorija, bibliotēka u. c.) tiesîbsargājošo iestāžu amatpersonu izglītošanas vajadzībām. Turpmākā Juridiskās fakultātes attīstība plānota ciešākā sadarbībā ar Medicīnas, Sabiedrības veselības un sociālās labklājības, kā arī citām fakultātēm, izmantojot šo fakultāšu resursus. Piemēram, izmantojot pozitronu emisijas tomogrāfiju, var lietot tā saucamo "smadzeṇu pirkstu nospiedumu metodi" (angḷu val. brain fingerprinting) [5]. Metodika dod iespējas atjaunot un vizualizēt atminu fragmentus, kuri saistīti ar cilvēka iepriekšējo darbību vai apstākḷiem, kādos viṇš ir atradies. Magnētiskā stimulācija sekmē smadzeṇu segmentu aktivizāciju. Veicot pārrunas ar indivīdu (aptauju, nopratināšanu), tiek noteikta viṇa reakcija uz noteiktiem vārdiem, frāzēm, attēliem un lietām, ko varētu izmantot, izzinot personas saistību ar konkrētiem noziedzīgiem nodarijumiem [11].

Tiesībsargājošo iestāžu vadītāji atzīst, ka trūkst kvalificētu speciālistu ekonomisko un finanšu noziegumu izmeklēšanā, kriminālvajāšanā un tiesas izmeklēšanā. Lai kaut daḷēji kompensētu šo speciālistu trūkumu, pašreiz fakultātē tiek izstrādāta profesionālā magistrantūras studiju programma "Ekonomiskā drošība". 
RSU Juridiskā fakultāte pastāvīgi attīstās un pilnveidojas atbilstoši laika rituma prasībām. Fakultātē cenšas sagatavot zinošus, prasmīgus un kompetentus speciālistus, tās misija ir veicināt studējošo motivāciju mācīties un nostiprināt iemaṇas patstāvīgi apgūt inovatīvo vidi.

\section{Secinājumi}

1. Sociāli politiskās, ekonomiskās un tiesiskās vides izmaiṇas rada nepieciešamību pārveidot arī augstākās izglìtības sistēmu, lai sniegtu jaunas zināšanas, izmantojot starpdisciplināru pieeju un modernas izglìtības metodes un tehnolog̣ijas.

2. Globālā sabiedrības attīstība un transnacionālā vide skar arī tiesisko sistēmu, tiesībsargājošo iestāžu darbību, izraisot objektīvu nepieciešamību optimizēt juristu sagatavošanas organizatoriskos un saturiskos procesus.

3. Apgalvojumi, ka Latvijā samazinās juridiskās izglìtības kvalitāte un tiesību zinātṇu studiju programmu absolventiem ir vājas zināšanas un prasmes jurisprudencē, nav pietiekami empīriski pamatoti. Pētijumi un apkopojumi šajā jomā nav veikti, tāpēc šādi secinājumi ir demagoğiski.

4. Centieni paaugstināt juridiskās izglītības kvalitāti un tiesību zinātṇu studiju programmu absolventu zināšanas un prasmes jurisprudencē, ieviešot vienotu valsts juristu kvalifikācijas eksāmenu, ir visai interesanti, bet vienlaikus tas ir arī komplicēts eksperiments. Tā īstenošanai nepieciešams izstrādāt pārbaudījumu metodiku, kurā būtu noteikti skaidri kritēriji, saturs un prasības valsts vienotā jurista kvalifikācijas eksāmena vērtēšanas pieejai. Tikpat sarežg̀ìta var būt arī valsts vienotā juristu kvalifikācijas eksāmena organizēšana elektroniskajā vidē.

5. Pašreiz ir pāragri secināt, vai valsts vienotā juristu kvalifikācijas eksāmena ieviešana patiešām paaugstinās juridiskās izglitīibas kvalitāti un tiesību zinātṇu studiju programmu absolventiem paaugstinās zināšanas un prasmes jurisprudencē.

\section{New Challenges for Legal Education}

\section{Abstract}

Political planning documents recognise that quality of legal education is decreasing in Latvia, graduates of law study programmes have poor knowledge and skills in jurisprudence. In order to increase the quality of legal education, the Cabinet of Ministers of the Republic of Latvia in 2015 accepts the order on the introduction of the State Unified Lawyer's Qualification Exam in 2021 in the professional Master's study programme "Law Science". At the same time, the higher education system eliminates professional bachelor study programmes and prevents students from gaining legal counsel. The higher legal 
education system as a whole is transformed. The introduction of the State Jurisprudence Expert Examination determines the necessity to transform the study process, to make changes in the study courses to be implemented, to supplement the requirements in the sub-branches of law, where students' knowledge in a single examination will be checked. Currently, it is too early to conclude whether the introduction of a single national lawyers' qualification examination will increase the quality of legal education, and graduates of legal science study programmes will increase their knowledge and skills in jurisprudence.

Keywords: lawyer, legal education law science, state lawyer qualification examination.

\section{Avoti un literatūra}

\section{Tiesību akti}

1. Augstskolu likums: Latvijas Republikas likums. Latvijas Vēstnesis. 179(462), 17.11.1995. Iegūts no: https://likumi.lv/doc.php?id=37967 [sk. 01.05.2019.].

2. Izglitīibas likums: Latvijas Republikas likums. Latvijas Republikas Augstākās Padomes un Valdības Ziñotājs. 31/32, 15.08.1991. Iegūts no: http://www.likumi.lv/doc.php?id=67960\&mode=DOC [sk. 30.05.2019.].

3. Par Valdības rīcỉbas plānu Deklarācijas par Laimdotas Straujumas vadītā Ministru kabineta iecerēto darbību īstenošanai: Latvijas Republikas Ministru kabineta 2015. gada 16. februāra rīkojums Nr. 78. Likumi.lv Iegūts no: https://m.likumi.lv/doc.php?id=272247 [sk. 15.05.2019.].

4. Profesionālās izglìīibas likums: Latvijas Republikas likums. Latvijas Vēstnesis. 213/215(1673/1675), 30.06.1999. Iegūts no: https://likumi.lv/doc.php?id=2024.4 [sk. 12.06. 2019.].

\section{Literatūra}

5. An Overview of the Impact of Neiroscience Evidence in Criminal Law. The President's Council on Bioethics. 2004. Iegūts no: http://bioethics.georgetown.edu/pcbe/background/neuroscience_evidence.html [sk. 01.06.2019.].

6. Briede, J. 1999. Publiskās un privātās tiesības. No: Mūsdienu tiesību teorijas atzinas: Mācību grāmata. Rakstu krājums prof. E. Meḷkiša red. Rīga: Tiesu namu aǵentūra.

7. Gaveiko, A. Juridiskās izglìtïbas reformu tendences Latvijā. Society. Integration. Education. Proceedings of the International Scientific Conference. Vol. 1, May 25th-26th, 2018, 113-123. Rëzeknes Tehnoloğiju akadēmija. Iegūts no: https://pdfs.semanticscholar.org/ca99/1b9fb534b 507b6eb4417f19d41bf07295a37.pdf [sk. 01.06.2019.].

8. Informatīvais ziṇojums "Par valsts vienotā jurista kvalifikācijas eksāmena ieviešanu": Latvijas Republikas Ministru kabineta tiesību akta projekts: 23.10.2015. Iegūts no: http://tap.mk.gov.lv/ $\mathrm{mk} / \mathrm{tap} /$ ?pid=40358096 [sk. 12.05.2019.].

9. Medicinas tiesības. Rìga: Tiesu namu ag̉entūra, 2015.

10. Pacientu tiesību likuma komentāri. Rīga: Latvijas Vēstnesis, 2019.

11. Vilks, A. (2015). Psiho- un neirotehnoloǵijas un sabiedriskās drošības problēmas. Socrates: 2015, 1(1). RSU elektroniskais juridisko zinātnisko rakstu žurnäls. Iegūts no: https:// www.rsu.lv/sites/default/files/imce/Dokumenti/izdevumi/socrates_1_2015.pdf [sk. 20.06.2019.]. 